with rnodern oloctronic or other physical apparatus and the principles and applications of engineering and mathematical techniquos. Each annual course comprises lectures, tutorials and laboratory instruction, occupying ten months of full-time study. A specialized laboratory has been established that is well equipped for training in the electrical and mechanical principles that are involved in physiological research and instrumentation. Instruction is provided in the use of oloctronic circuits and semiconductor devices, in automatic data-handling, in the use of analogue and digital computers, and in other aspects of physies and engineoring having application in medicine and biology. Further information concorning these bursaries can be obtained from tho Registrar, Imperial College of Science and Technology, London, S.W.7.

\section{Award for Biomagnetic Research}

${ }^{T}$ THE Biomagnetic Resoarch Foundation is offering an award of 1,000 U.S. dollars for the development of a classic experiment demonstrating with simple means a biological effect of a static magnetic field. The best experiment will be chosen at the second Biomagnetic Symposium in November 1963 and repeated within one year by J. M. Barnothy and M. F. Barnothy on behalf of the Biomagnetic Research Foundation. To qualify for the competition, the experiment has to meet the following conditions: the treatment of the live animals or specimens in vivo should not necessitate a more extended, stronger or more inhomogeneous magnetic field than that which can be produced with pole pieces with a Varian 4-in. electromagnet. Tho treatment time should not exceed $200 \mathrm{~h}$ in the field. The biological effect should be observable after treatment, but within a timo interval of 6-100 h after removal of the specimen from the field. The effect must be demonstrated on an adequately large number of specimens, to ensure a probability-level better than 1:10,000. The experiment should be of such nature that the influence of uncontrollable environmental factors, such as variation of the Earth's magnetic elements, sunspot activities, barometric pressure, cosmic radiation, Moon phases, etc., can be considered as negligible. Fuller details of the conditions of the award can be obtained from the Biomagnetic Research Foundation, 833 Lincoln Street, Evanston, Illinois.

\section{Southern Pennines Geological Conference}

DURing recent years there has been a great revival of interest in the geology of the Southern Ponnines, more especially in the Carboniferous rocks of the region. This has been due in no small measure to a large increase in the number of research students, and to the evolution of new techniques both in the field and in the laboratory. The renewed activity has lod inevitably to a cortain amount of overlap, and there have been several instances in which a partial or even complete overlap of research interests has been discovered only at a late stage of the investigations. In order to co-ordinate research effort, and to facilitate contact between all those actively interested in the area, whether amateur or professional, a conference was held at the University of Keole during September 24-26. Prof. F. W. Cope (Keele) welcomed the delegates and gavo a short introductory address on the first evening of the meeting, and, on the following two days, papers with reports of work in progress, or recently completed, were read by Prof. F. W. Shotton, Dr. F. M. Broad- hurst, Dr. T. D. Ford, Dr. H. G. Reading, Dr. H. E. Sadler, Dr. A. A. Wilson, Mr. R. H. Johnson and Mr. B. K. Holdsworth. Following the suceess of the conference, it was decided that a second one should be held at Koele during September 1963. Dr. M. H. Mason, of the Geology Department, Keele, who acted as honorary secretary, will continue in that capacity for the 1963 meeting.

\section{Announcements}

Sir WiLlis JACkson, professor of electrical engin oering, Imperial College of Science and Tochnology, has been appointed chairman of the Television Advisory Committee. As such, Sir Willis succeods Sir Charles Daniel, who has resigned after serving as chairman for ten years. The Committee was set up by the Postmaster-Genoral to advise him on the development of television broadcasting and veryhigh-frequency sound broadcasting.

The Biochemical Socioty of France has awardod the 1962 Charles Leopold Mayer Prize to M. François Chapeville for his work leading to the demonstration of the importance of cortain ribonucleic acids in passing on genetic information. M. Chapeville has been working under Dr. P. Fromagoot at Saclay and has also carried out resoarch in the United States with Dr. F. A. Lipmann on the reactions that enable tho living cell to condense amino-acids into protein macromolecules. The prize, which is awarded annually for notable research work on the nucleic acids and nuclooproteins, is valued at $5,000 \mathrm{~N} . \mathrm{F}$.

A colloquium on clinical and diagnostic aspects of enzyme multiplicity is to be held at the University of Ghent on April 27. The colloquium is being organized by the University in collaboration with the Belgian Society for Clinical Chemistry. Further information can be obtained from Prof. R. J. Wieme, Laboratory of the Medical Clinic, University of Ghent, Pasteurdreef 2, Ghent.

A speciar meeting of the Iron and Steol Institute will be held in India during the early spring, at the invitation of the Indian Institute of Metals and the National Metallurgical Laboratory, Jamshedpur. The programme will include a symposium on "Recent, Developments in Tron and Steelmaking with Special Reference to Indian Conditions", and visits to various Indian steelworks. Further information can be obtained from K. Headlam-Morley, The Iron and Steel Institute, 4 Grosvenor Gardens, London, S.W.1.

A Two-DAY symposium, entitled "The Nature, Synthesis and Activity of Enzymes", will be held at the Luton College of Technology during April 18-19. The subjects under consideration include: isolation of pure enzymes; studies on the amino-acid sequence and the active site; following the progress of enzyme reactions; organization of the cell; mechanism of protein biosynthesis; control of enzyme synthesis in cells. Further information can be obtainod from the Registrar, Luton College of Tochnology, Luton, Bedfordshire.

IT is regretted that the announcement on p. 324 of Nature of October 27 relating to Dr. R. A. Pattle was in error. This should have referred to Dr. R. E. Pattle, who is on the staff of the Chemical Defonce Experimental Fistablishment. $\mathrm{H} \theta$ is best known for his identification of the lining film which lowers the surface tension of the lung alveoli. He has also carried out work on the toxicology of atmospheric pollution. 